\title{
Ubiquitin Carboxyl-Terminal Hydrolase Isozyme L5
}

National Cancer Institute

\section{Source}

National Cancer Institute. Ubiquitin Carboxyl-Terminal Hydrolase Isozyme L5. NCI

Thesaurus. Code C158570.

Ubiquitin carboxyl-terminal hydrolase isozyme L5 (329 aa, $~ 38 \mathrm{kDa}$ ) is encoded by the human UCHL5 gene. This protein plays a role in chromatin modification and the removal of lysine-48-linked polyubiquitin chains from substrate proteins. 